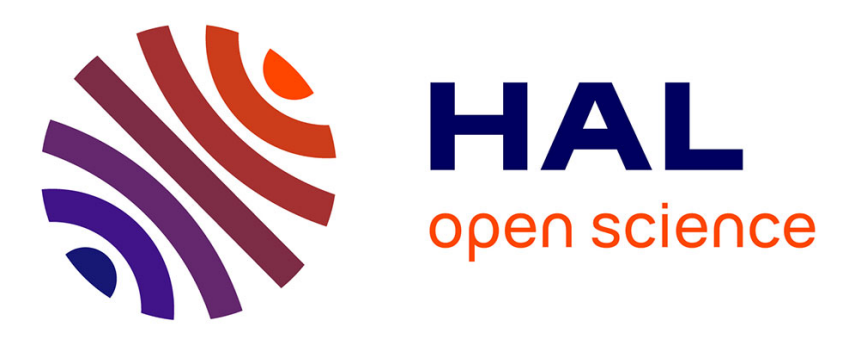

\title{
Magnetic Characterization of Bacterial Magnetic Particles
}

H. Nishio, T. Takahashi, H. Taguchi, S. Kamiya, T. Matsunaga

\section{To cite this version:}

H. Nishio, T. Takahashi, H. Taguchi, S. Kamiya, T. Matsunaga. Magnetic Characterization of Bacterial Magnetic Particles. Journal de Physique IV Proceedings, 1997, 07 (C1), pp.C1-663-C1-666. 10.1051/jp4:19971271 . jpa-00254983

\section{HAL Id: jpa-00254983 https://hal.science/jpa-00254983}

Submitted on 1 Jan 1997

HAL is a multi-disciplinary open access archive for the deposit and dissemination of scientific research documents, whether they are published or not. The documents may come from teaching and research institutions in France or abroad, or from public or private research centers.
L'archive ouverte pluridisciplinaire $\mathbf{H A L}$, est destinée au dépôt et à la diffusion de documents scientifiques de niveau recherche, publiés ou non, émanant des établissements d'enseignement et de recherche français ou étrangers, des laboratoires publics ou privés. 


\title{
Magnetic Characterization of Bacterial Magnetic Particles
}

\author{
H. Nishio, T. Takahashi, H. Taguchi, S. Kamiya* and T. Matsunaga** \\ Materials Research Center, TDK Corporation, 570-2, Aza-Matsugashita, Minami-Hatori, Narita 286, \\ Japan \\ * TDK Akita Laboratory Corporation, 15 Aza-Gashomen, Hirasawa, Nikaho-machi, Yuri-gun, \\ Akita 018-04, Japan \\ ** Tokyo University of Agriculture and Technology, 2-24-16, Nakamachi, Koganei 184, Japan
}

\begin{abstract}
Mossbauer measurement, chemical analysis (ratio of $\mathrm{Fe}^{2+}$ to total $\mathrm{Fe}$ content), analyses of the rotational hysteresis loss $(\mathrm{Wr})$ and the magnetic viscosity coefficient ( $\mathrm{Sv}$ ) for bacterial magnetic particles covered with organic thin films (BMPs) were investigated and compared with the results for $\mathrm{Fe}_{3} \mathrm{O}_{4}$ fine particles prepared by a chemical coprecipitation method. The calculated value of the saturation magnetization (Js) of BMPs was found to be $1.06 \times 10^{-4} \mathrm{~Wb} \mathrm{~m} / \mathrm{kg}(84.7 \mathrm{emu} / \mathrm{g})$ using M8ssbauer spectroscopy and chemical analysis. The $\mathrm{Wr} / \mathrm{Js}$ versus $\mathrm{H}$ curve for $\mathrm{BMPs}$ had a stronger peak than that of $\mathrm{Fe}_{3} \mathrm{O}_{4}$ fine particles (Sample C1). The rotational hysteresis integrals $(\mathrm{Rh})$ for BMPs and $\mathrm{Fe}_{3} \mathrm{O}_{4}$ fine particles were 1.12 and 0.62 , respectively. It is believed that they have different magnetization reversal mechanisms. The Sv value of $\mathrm{BMPs}$ at $127 \mathrm{~A} / \mathrm{m}$ was $50 \%$ smaller than that of the $\mathrm{Fe}_{3} \mathrm{O}_{4}$ fine particles (C1). The diameter (Dact) of the activation volume (minimum volume for magnetization reversal) calculated from $\mathrm{Sv}$, and the critical diameter (Dc) obtained by considering the superparamagnetic behavior for BMPs, were 39 and $22 \mathrm{~nm}$, respectively. As the $\mathrm{Fe}_{3} \mathrm{O}_{4}$ fine particles $(\mathrm{C} 1)$ have smaller Dact $(31 \mathrm{~nm})$ and $\mathrm{Dc}(18 \mathrm{~nm})$, it may be concluded that $\mathrm{BMPs}$ is magnetically more stable than $\mathrm{Fe}_{3} \mathrm{O}_{4}$ fine particles (C1).
\end{abstract}

\section{INTRODUCTION}

Magnetic bacteria contain crystalline magnetic particles which cause them to orient in the presence of an external magnetic field and swim along the field lines. Magnetospirillum sp. strain AMB-1 is a freshwater magnetic bacterium which synthesizes intracellular magnetic particles[1]. The ecological significance of these biological magnets remains unclear and the mechanism of magnetic particles synthesis in magnetic bacteria has not been elucidated, although it has been proposed that sensitivity to the geomagnetic field allows oxygen sensitive magnetic bacteria to swim downward into oxygen-poor sediments, their preferred habitat. Purified bacterial magnetic particles(BMPs) are smaller in size (30-100 $\mathrm{nm}$ ) and disperse very well because they are covered with organic thin films which consist of stable lipid membrane. Large quantities of bioactive substances may be immobilized on BMPs due to the presence of this membrane. For this reason, BMPs have been investigated for enzyme, antibody and DNA carriers[2]. It is particularly important to study the saturation magnetization (Js) without the organic thin film, the mechanism of magnetization reversal and the magnetic stability in order to enhance the application of BMPs. This paper reports on studies of Mössbauer measurement, chemical analysis (ratio of $\mathrm{Fe}^{2+}$ to total $\mathrm{Fe}$ content), analyses of the rotational hysteresis loss (Wr), the magnetic viscosity coefficient (Sv) and the activation volume (Vact : minimum volume of magnetization reversal) for BMPs covered with organic thin films. Also, the results of $\mathrm{Fe}_{3} \mathrm{O}_{4}$ fine particles having various particle diameters prepared by a chemical coprecipitation method will be compared.

\section{EXPERIMENTAL}

AMB-1 was cultured anaerobically in a MSGM ( $\mathrm{pH} 6.75)$ at $25^{\circ} \mathrm{C}$. The cells grown to stationary phase were harvested by centrifugation at $5 \mathrm{kG}$ for $20 \mathrm{~min}$. The harvested cells (about $10 \mathrm{~g}$ wet weight) were washed with Lysis buffer ( $\mathrm{pH} \mathrm{8.0}$ ) and treated with lysozyme $\left(37^{\circ} \mathrm{C}, 40 \mathrm{~min}\right)$ and proteinase $\left(55^{\circ} \mathrm{C}, 8 \mathrm{~h}\right)$ in order to isolate BMPs. The BMPs were collected from the enzyme treated cell fraction using a Sm-Co magnet $(0.4 \mathrm{~T})$. They were collected at the bottom of the tube using the magnet and the supernatant was removed. The BMPs covered with organic thin films (about $13 \mathrm{mg}$ ) were washed with distilled water twice.

Table 1 shows particle diameter (D), the saturation magnetization (Js) and coercive force $(\mathrm{Hc})$ for $\mathrm{Fe}_{3} \mathrm{O}_{4}$ single crystal, BMPs and $\mathrm{Fe}_{3} \mathrm{O}_{4}$ fine particles ( $\mathrm{C} 1, \mathrm{C} 2, \mathrm{C} 3$ and $\mathrm{C} 4$ ) prepared by a chemical coprecipitation method. D was observed using TEM and SEM. The values of Js and Hc were measured using a vibrating sample magnetometer (VSM). The value of Js for BMPs cannot be obtained using a VSM because they are placed on approximately $2.5 \mathrm{~nm}$ thick organic thin films. In this study, the existence of $\gamma-\mathrm{Fe}_{2} \mathrm{O}_{3}$ in the samples was suspected. The value of $\mathrm{Js}$ for BMPs was calculated from the ratio of $\mathrm{Fe}^{2+}$ to total $\mathrm{Fe}$ content obtained using Mössbauer spectrum and the results of chemical analysis. 
Mössbauer measurements at $25^{\circ} \mathrm{C}$ were performed using a conventional, constant acceleration spectrometer with a ${ }^{57} \mathrm{Co}$ source in a $\mathrm{Rh}$ matrix. The spectra were least-squares fitted using a computer, assuming Lorentzian line shapes. When the recoilfree fraction is a constant, the number of atoms of Fe per unit volume in the absorber is proportional to the effective thickness[3]. The ratio of the number of $\mathrm{Fe}$ ions for $\left(\mathrm{Fe}^{2+} / \mathrm{Fe}^{3+}\right)$ in $\mathrm{Fe}_{3} \mathrm{O}_{4}$ to the total number of $\mathrm{Fe}$ ions in a sample comprising a mixture of $\mathrm{Fe}_{3} \mathrm{O}_{4}$ and $\gamma-\mathrm{Fe}_{2} \mathrm{O}_{3}$ is given by the equation:

$$
\mathrm{R}=3 / 2(1+\mathrm{SA} / \mathrm{SB})
$$

Table 1 Particle diameter $\mathrm{D}$, the saturation magnetization $J_{s}$ and coercive force $\mathrm{Hc}$ of $\mathrm{Fe}_{3} \mathrm{O}_{4}$ single crystal, bacterial magnetic particles (BMPs) and $\mathrm{Fe}_{3} \mathrm{O}_{4}$ particles (C1, C2, C3 and $\mathrm{C} 4$ ) prepared by the chemical coprecipitation method. Sample D $(\mathrm{nm})$ Js $\left.\times 10^{-4} \mathrm{~Wb} \mathrm{~m} / \mathrm{kg}\right) \mathrm{Hc}(\mathrm{kA} / \mathrm{m})$

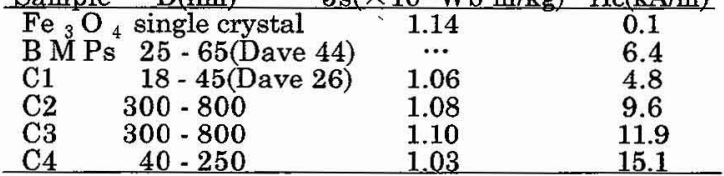

where $S_{A}$ and $S_{B}$ are the peak areas at -7.7 and $-6.7 \mathrm{~mm} / \mathrm{s}$. Therefore, $(1-R)$ corresponds to the ratio of the number of ions of $\mathrm{Fe}$ in $\gamma-\mathrm{Fe}_{2} \mathrm{O}_{3}$ to the total in the sample. In this experiment, $\mathrm{Js}$ values measured using a VSM for $\mathrm{Fe}_{3} \mathrm{O}_{4}$ single crystal and $\gamma-\mathrm{Fe}_{2} \mathrm{O}_{3}$ particles were 1.14 and $0.96 \times 10^{-4} \mathrm{~Wb} \mathrm{~m} / \mathrm{kg}(90.7$ and $76.4 \mathrm{emu} / \mathrm{g})$, respectively.

The chemical analysis was carried out as follows. The samples were dissolved in $\mathrm{HCl}$ under $\mathrm{N}_{2}$ flow. Fe ${ }^{2+}$ was determined by spectrophotometry using O-phenanthrolin. The total amount of Fe was also determined by spectrophotometry using $O$-phenanthrolin after reducing with hydroxylamine hydrochloride.

The magnetic field $(\mathrm{H})$ dependence of the rotational hysteresis loss (Wr) was measured using a torque magnetometer to study the distribution of the anisotropy field (HA), the average anisotropy field (HA, ave) and the mechanism of magnetization reversal. The Wr and the rotational hysteresis integrals (Rh), which corresponds to the mechanism of magnetization reversal, can be expressed as [4,5]:

$$
\begin{aligned}
& \mathrm{Wr}=\int \mathrm{L} \mathrm{d} \theta=\mathrm{Js} / 2 \int \mathrm{HA} \cdot \sin 2 \phi \cdot \mathrm{d} \theta \\
& \mathrm{Rh}=\int \mathrm{Wr} / \mathrm{Js}_{\mathrm{s}} \mathrm{d}(1 / \mathrm{H})
\end{aligned}
$$

where $\mathrm{L}$ is the torque, $\theta$ and $\phi$ are angles between the easy axis and, $\mathrm{H}$ and $\mathrm{Js}$,

HA, ave corresponds to half of the peak value of the Wr versus $1 / \mathrm{H}$ curve at high magnetic field[6]. The critical volume (Vc) for superparamagnetic behavior can be expressed as follows[7];

$$
\mathrm{Vc}=50 \mathrm{kT} / \mathrm{Js} \mathrm{HA} \text {, ave }
$$

The magnetic viscosity coefficient (Sv), which had been described as the fluctuation field (Hf) [8], is an important factor which essentially determines the magnetic stability. It is known to depend on Sv, the irreversible susceptibility (Xirr) and the logarithmic time (ln t) $[8,9]$. When the change in magnetization from time $t_{1}$ to $t_{2}(\Delta J)$ is considered, Sv can be expressed using the following equation[8-10]:

$$
\mathrm{Sv}=\Delta \mathrm{J} / \mathrm{Xim}\left(\ln \mathrm{t}_{1}-\ln \mathrm{t}_{2}\right)=\mathrm{kT} /(\partial \mathrm{E} / \partial \mathrm{H}) \mathrm{T}=\mathrm{kT} / \text { Vact Js }
$$

where $\mathrm{E}$ is the activation energy and Vact is the activation volume.

After the application of $1.6 \mathrm{MA} / \mathrm{m}$, the samples were subjected to a constant magnetic field $(H)$ for $1000 \mathrm{~s}$ and $\Delta \mathrm{J}$ was measured using a VSM[11].The reversible susceptibility (Xrev) and the total differential susceptibility (Xtot), obtained by differentiating the demagnetizing curve with respect to $H$, were also measured using a VSM. Xirx can be expressed by Xtot - Xrev.

\section{RESULTS AND DISCUSSION}

As shown in Table 1, $\mathrm{Fe}_{3} \mathrm{O}_{4}$ fine particles $(\mathrm{C} 1, \mathrm{C} 2, \mathrm{C} 3$ and $\mathrm{C} 4)$ prepared by a chemical coprecipitation method had saturation magnetization (Js) about $3-9 \%$ smaller than that of the $\mathrm{Fe}_{3} \mathrm{O}_{4}$ single crystal. In order to clarify this reason, powder X-ray diffraction was measured by step scanning method as shown in Figure 1 . It is apparent from the XRD pattern that the $\gamma-\mathrm{Fe}_{2} \mathrm{O}_{3}$ phase existed in $\mathrm{C} 4$, though this phase was not observed in $\mathrm{C} 2$ and C3. From the XRD pattern for $\mathrm{C} 1$, it seems that the $\gamma-\mathrm{Fe}_{2} \mathrm{O}_{3}$ phase was present in small quantities, and the broadness of peak patterns was influenced by peak splitting due to the mixture of $\gamma-\mathrm{Fe}_{2} \mathrm{O}_{3}$ and $\mathrm{Fe} \mathrm{O}_{3} \mathrm{O}_{4}$. However, due to insufficient resolution, the existence of $\gamma-\mathrm{Fe}_{2} \mathrm{O}_{3}$ could not be confirmed. Therefore, Mössbauer measurement and chemical analysis were performed in order to obtain the ratio of $\mathrm{Fe}^{2+}$ to total Fe content. The Mössbauer spectra of all samples shown in Table 1 were measured at $25^{\circ} \mathrm{C}$ and the results for BMPs and C1 are given in Figures 2 and 3 . A paramagnetic doublet was not found and these spectra consist of magnetic hyperfine lines between approximately +8 and $-8 \mathrm{~mm} / \mathrm{s}$. In general, magnetite $\left(\mathrm{Fe}_{3} \mathrm{O}_{4}\right)$ has a cubic spinel structure with iron in both tetrahedral (A sites) and octahedral (B sites) crystal lattice sites: $\left(\mathrm{Fe}^{3+}\right)(\mathrm{A})\left[\mathrm{Fe}^{2+} \mathrm{Fe}^{3+}\right](\mathrm{B}) \mathrm{O}_{4}$. Thus, the stoichiometric $\mathrm{Fe}_{3} \mathrm{O}_{4}$ has two distinct sextets in 1:2 intensity ratio at room temperature, corresponding to A sites with hyperfine field Hhf $=39.0 \mathrm{MA} / \mathrm{m}$, and $\mathrm{B}$ sites with $\mathrm{Hhf}=36.6 \mathrm{MA} / \mathrm{m}[12]$. Maghemite $\left(\gamma \cdot \mathrm{Fe}_{2} \mathrm{O}_{3}\right)$ is obtained by completely oxidizing $\mathrm{Fe}_{3} \mathrm{O}_{4}$. It also contains iron in tetrahedral $\mathrm{A}$ and octahedral $B$ sites, but there are vacancies (usually B sites) to compensate for the increased positive charge. Thus, in analogy to $\mathrm{Fe}_{3} \mathrm{O}_{4}$, the stoichiometry can be represented as $\left(\mathrm{Fe}^{3+}\right)(\mathrm{A})[\square \mathrm{I} / 3$ $\left.\mathrm{Fe}^{3+} 5 / 3\right](\mathrm{B}) \mathrm{O}_{4}$, and the $\mathrm{Hhf}$ value is $39.7 \mathrm{MA} / \mathrm{m}$ [12], which is almost the same value in the $A$ sites of $\mathrm{Fe}_{3} \mathrm{O}_{4}$.

The curve-fitting parameter of line width $(\Gamma)$ and Hhf, which are obtained from Mössbauer spectra, are shown in Table 2 along with the peak area of $\mathrm{SA}$ and $\mathrm{SB}$ for all samples. The magnetic sextet for

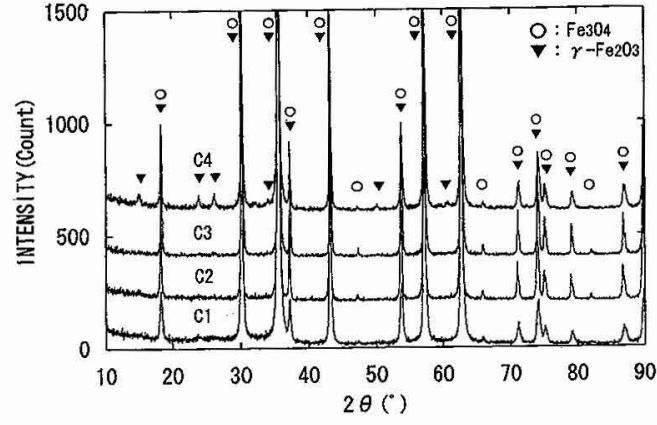

Figure $1 \mathrm{X}$ ray diffraction patterns of $\mathrm{Fe}_{3} \mathrm{O}_{4}$ fine particles prepared by the chemical coprecipitation method. 


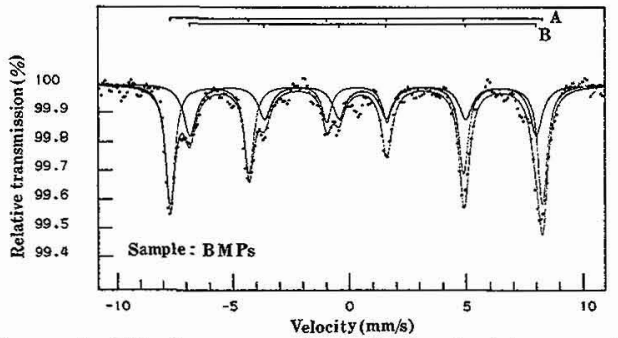

Figure 2 Mössbauer spectrum for bacterial magnetic. particles (BMPs).

$\mathrm{C} 2$ and $\mathrm{C} 3$ had Hhf of 39.2 (A sites) and $36.6 \mathrm{MA} / \mathrm{m}$ (B sites), corresponding to $\mathrm{Fe}_{3} \mathrm{O}_{4}$ single crystal[12].

The line width $(\Gamma)$ in $B$ sites had especially broad values for $\mathrm{C} 1$ and $\mathrm{C} 4$. Moreover, Hhf for $\mathrm{C} 1$ was 35.9 $\mathrm{MA} / \mathrm{m}$, the smallest value in $\mathrm{B}$ sites. These results showed the possible existence of a small amount of superparamagnetic particles in $\mathrm{C} 1$. The ratio of $\mathrm{wt} \%$ $\mathrm{Fe}$ of $\mathrm{Fe}_{3} \mathrm{O}_{4}$ and $\gamma-\mathrm{Fe}_{2} \mathrm{O}_{3}$ obtained from Eq.(1) using the values of peak area ( $\mathrm{S}_{\mathrm{A}}$ and $\mathrm{SB}_{B}$ ) are shown in Table 3 along with the saturation magnetization (Js,mos) calculated from wt\% Fe. For C1, C2, C3 and $\mathrm{C4}$, the values of $\mathrm{Js}, \mathrm{mos}$ were consistent with those of Jsmeasured using a VSM as shown in Table 1. The calculated value of Js, mos for BMPs was found to be $1.06 \times 10^{-4} \mathrm{~Wb} \mathrm{~m} / \mathrm{kg}(84.7 \mathrm{emu} / \mathrm{g})$.

Table 4 shows the ratio of $\mathrm{Fe}^{2+}$ to total $\mathrm{Fe}$ content obtained using both Mössbauer spectroscopy and

Table 3 The value of $w \mathrm{t} \% \mathrm{Fe}$ and saturation magnetization Js, mos for $\mathrm{Fe}_{3} \mathrm{O}_{4}$ single crystal, $\gamma-\mathrm{Fe}_{2} \mathrm{O}_{3}$ fine particles, bacterial magnetic particles (BMPs) and $\mathrm{Fe}_{3} \mathrm{O}_{4}$ particles (C1, C2, C3 and $\mathrm{C} 4)$ prepared by the chemical coprecipitaion method using Mössbauer spectroscopy.

\begin{tabular}{|c|c|c|c|}
\hline \multirow[t]{2}{*}{ Sample } & \multicolumn{2}{|c|}{ wt $\% \mathrm{Fe}$} & $\mathrm{J}_{\mathrm{s}, \mathrm{mos}}$ \\
\hline & $\mathrm{Fe}_{3} \mathrm{O}_{4}$ & $\gamma-\mathrm{Fe}_{2} \mathrm{O}$ & $\times 10^{-4} \mathrm{~Wb} \cdot \mathrm{m} / \mathrm{kg}$ \\
\hline $\mathrm{Fe}_{3} \mathrm{O}_{4}$ & 100 & 0 & 1.14 \\
\hline $\begin{array}{l}\text { single crystal } \\
\gamma \cdot \mathrm{Fe}_{2} \mathrm{O}_{3}\end{array}$ & 0 & 100 & 0.96 \\
\hline BMPs & 59.7 & 40.3 & 1.06 \\
\hline $\mathrm{C} 1$ & 62.8 & 37.2 & 1.07 \\
\hline $\mathrm{C} 2$ & 73.8 & 26.2 & 1.09 \\
\hline C3 & 81.7 & 18.3 & 1.10 \\
\hline $\mathrm{C} 4$ & 47.2 & 52.8 & 1.04 \\
\hline
\end{tabular}

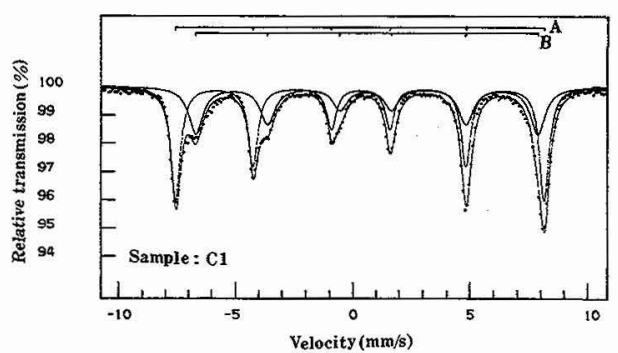

Figure 3 Mössbauer spectrum for $\mathrm{Fe}_{3} \mathrm{O}_{4}$ fine particles (C1) prepared by the chemical coprecipitation method.

Table 2 The curve-fitting parameters for $\mathrm{Fe}_{3} \mathrm{O}_{4}$ single crystal, bacterial magnetic particles (BMPs) and $\mathrm{Fe}_{3} \mathrm{O}_{4}$ particles (C1, C2, C3 and C4) prepared by the chemical coprecipitation method

\begin{tabular}{lcccc}
\multicolumn{5}{c}{ coprecipitation method. } \\
Sample & Sites & $\Gamma(\mathrm{mm} / \mathrm{s})$ & Hhf(MA/m) & $\mathrm{S}(\%)$ \\
\hline Fe3O4 & $\mathrm{A}$ & $\mathbf{0 . 2 4} \pm 0.01$ & 38.8 & $33 \pm 2$ \\
single crystal & $\mathrm{B}$ & $0.33 \pm 0.01$ & 36.4 & $67 \pm 2$ \\
$\mathrm{~B} \mathrm{M} \mathrm{Ps}$ & $\mathrm{A}$ & $0.47 \pm 0.04$ & 39.4 & $61 \pm 2$ \\
& $\mathrm{~B}$ & $0.60 \pm 0.09$ & 36.5 & $39 \pm 2$ \\
$\mathrm{C} 1$ & $\mathrm{~A}$ & $0.49 \pm 0.01$ & 38.8 & $\mathbf{5 9 \pm 2}$ \\
& $\mathrm{B}$ & $0.76 \pm 0.03$ & 35.9 & $41 \pm 2$ \\
$\mathrm{C} 2$ & $\mathrm{~A}$ & $0.41 \pm 0.01$ & 39.2 & $\mathbf{5 2} \pm 2$ \\
& $\mathrm{~B}$ & $0.64 \pm 0.03$ & 36.6 & $48 \pm 2$ \\
$\mathrm{C} 3$ & $\mathrm{~A}$ & $0.37 \pm 0.01$ & 39.2 & $47 \pm 2$ \\
& $\mathrm{~B}$ & $0.37 \pm 0.01$ & 36.6 & $\mathbf{5 3} \pm 2$ \\
$\mathrm{C} 4$ & $\mathrm{~A}$ & $0.50 \pm 0.01$ & 39.2 & $68 \pm 2$ \\
& $\mathrm{~B}$ & $0.70 \pm 0.07$ & 36.6 & $32 \pm 2$ \\
\hline
\end{tabular}

Table 4 The value of $\mathrm{Fe}^{2+} / \mathrm{T}$ tal $\mathrm{Fe}$ for $\mathrm{Fe}_{3} \mathrm{O}_{4}$ single crystal, $\gamma-\mathrm{Fe}_{2} \mathrm{O} 3$ fine particles, bacterial magnetic particles (BMPs) and $\mathrm{Fe}_{4} \mathrm{O}_{4}$ particles (C1, C2, C3 and $\left.\mathrm{C} 4\right)$ prepared by the chemical coprecipitation method using Mössbauer spectroscopy and chemical analysis. Sample $\quad \mathrm{Fe}^{2+} / \mathrm{Total} \mathrm{Fe}(\%)$

\begin{tabular}{lcc} 
& Mössbauer & chemical analysis \\
\hline $\mathrm{Fe}_{4} \mathrm{O}_{4}$ & 33 & 33 \\
single crystal & & \\
$\gamma$-Fe2O3 & 0 & 0 \\
$\mathrm{BMPs}$ & 20 & 19 \\
$\mathrm{C} 1$ & 21 & 17 \\
$\mathrm{C} 2$ & 25 & 23 \\
$\mathrm{C} 3$ & 27 & 27 \\
$\mathrm{C} 4$ & 16 & 17 \\
\hline
\end{tabular}

chemical analysis. The results of Mössbauer spectroscopy agree well with those obtained using chemical analysis. The increase of $\mathrm{Fe}^{2+}$ and vacancies is considered to be indicative of the existence of $\gamma-\mathrm{Fe}_{2} \mathrm{O}_{3}$ in solid solution with $\mathrm{Fe}_{3} \mathrm{O}_{4}$ in BMPs and $\mathrm{C1}$. The $\mathrm{J}_{\mathrm{s}}$ values for BMPs and $\mathrm{C} 1$ therefore decreased compared with that of the $\mathrm{Fe}_{3} \mathrm{O}_{4}$ single crystal.

The rotational hysteresis loss (Wr/Js) as a function of $\mathrm{H}$ is plotted in Figure 4. It may be understood from Eq. (2) that the Wr/Js versus H curve represents the distribution of $\mathrm{HA}$. The Wr/Js versus $H$ curve of BMPs had a stronger peak than that of $\mathrm{Fe}_{3} \mathrm{O}_{4}$ particles $(\mathrm{C} 1, \mathrm{C2}, \mathrm{C} 3$ and $\mathrm{C} 4)$. The distribution of HA for BMPs seems to be excellent. Since the half-value width of the $\mathrm{Wr} / \mathrm{Js}$ versus $\mathrm{H}$ curve of $\mathrm{C} 4 \mathrm{was}$ broad, the latter may comprise particles with various $\mathrm{HA}$ values. The rotational hysteresis integrals $(\mathrm{Rh}$ ) obtained from Eq. (3), using the values shown in Figure 4, were calculated to be 1.12,0.62, 0.67 and 0.67 for BMPs, C1, C2 and C3, respectively (Table 5). The Rh for BMPs is closer to the value calculated from the chain-of-spheres with fanning model in random alignment $(\mathrm{Rh}=1.02)$ [4]. However, $\mathrm{Rh}$ values for $\mathrm{C1}, \mathrm{C} 2$ and $\mathrm{C} 3$ are intermediate between coherent rotation model ( $\mathrm{Rh}=0.38-0.42$ ) [4] and the chain-of-spheres with fanning model in random alignment. It is believed that they have different magnetization reversal mechanisms. The $\mathrm{HA}$, ave obtained from the $\mathrm{Wr} / \mathrm{Js}$ versus $1 / \mathrm{H}$ curve at high field [6], were 35.8 and $68.5 \mathrm{kA} / \mathrm{m}$ for BMPs and $\mathrm{C} 1$, respectively (Table 5). The critical volumes (Vc) for superparamagnetic behavior for BMPs and C1 calculated from Eq.(4) using Js,mos shown in Table 3, were found to be $11 \times 10^{-24}(\mathrm{Dc}=22 \mathrm{~nm})$ and $6 \times 10^{-24} \mathrm{~m}^{3}(\mathrm{Dc}=18 \mathrm{~nm})$, respectively (Table 5). It was inferred from the results of Mössbauer spectroscopy and from the critical diameter (Dc) for superparamagnetic behavior that a small amount of very fine superparamagnetic particles exists in $\mathrm{Cl}$. As the size of the particles decreases, the magnetic viscosity increases, and further reduction in size finally results in superparamagnetism.

The magnetic field dependences of $\Delta \mathrm{J} /\left(\ln \mathrm{t}_{1}-\ln \mathrm{t}_{2}\right)$ and Xirr were measured at $25^{\circ} \mathrm{C}$ for $\mathrm{BMP}, \mathrm{C} 1, \mathrm{C} 2, \mathrm{C} 3$ and C4. A comparison of the magnetic field dependences of $\Delta J /\left(\ln t_{1}-\ln t_{2}\right)$ and Xirr shows that the shape of the curve for all samples is very similar.

Figure 5 shows the magnetic field dependence of the magnetic viscosity coefficient (Sv) for BMPs, C1, C2, C3 and $\mathrm{C} 4$ obtained from Eq.(5). This experiment shows that the range in which Sv stays at constant values, which 
are independent of the magnetic field $(\mathrm{H})$, is very wide. The Sv value of BMPs was $50 \%$ smaller than that of C1 which had the lowest coercive force $(\mathrm{Hc}=4.8 \mathrm{kA} / \mathrm{m})$ of these samples. Barbier's relation [13], which establishes that the logarithm of Sv varies in proportional to $\ln \mathrm{Hc}$ from soft to hard magnetic materials is generally known. The Sv value of $\mathrm{C1}$ was large compared to that of $\gamma-\mathrm{Fe}_{2} \mathrm{O}_{3}$ fine particles $(\mathrm{Sv}=96 \mathrm{~A} / \mathrm{m})$ used for recording media with higher $\mathrm{Hc}(28 \mathrm{kA} / \mathrm{m})$ [11]. The time dependence of magnetization for $\mathrm{C} 1 \mathrm{was}$ found to be $-7 \%$ after $1000 \mathrm{~h}$ at $60^{\circ} \mathrm{C}$. The values of Vact at $25^{\circ} \mathrm{C}$ for BMPs and $\mathrm{C} 1$ calculated from Eq. (5) using Sv and Js, mos, were found to be $61 \times 10^{-24}$ and $29 \times 10^{-24} \mathrm{~m}^{3}$, respectively (Table 5). The diameters (Dact) of Vact for BMPs and C1 were 39 and $31 \mathrm{~nm}$, respectively (Table 5). Dact values for BMPs and C1 were very close to that of the average particle diameter (Dave $=44$ and $26 \mathrm{~nm}$ ) shown in Table 1 . As C1 has a smaller Dc and Dact, it is concluded that BMPs is magnetically more stable than C1. Typical magnetic properties obtained in this study are shown in Table 7.

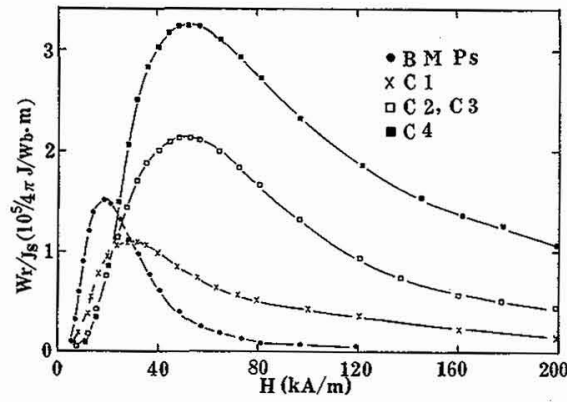

Figure 4. Plots of the rotational hysteresis loss $\mathrm{Wr} / \mathrm{Js}$ versus magnetic field $\mathrm{H}$ for bacterial magnetic particles (BMPs), $\mathrm{Fe}_{4} \mathrm{O}_{4}$ particles (C1, C2, C3 and C4) prepared by the chemical coprecipitation method.

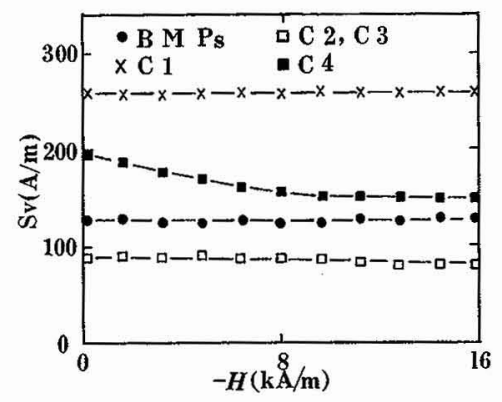

Figure 5. Magnetic field dependence of the magnetic viscosity coefficient $\mathrm{Sv}$ for bacterial magnetic particles (BMPs), $\mathrm{Fe}_{3} \mathrm{O}_{4}$ particles (C1, C2, C3 and C4) prepared by the chemical coprecipitation method.

Table 5 Average anisotropy field $\mathrm{HA}$, ave, the rotational hysteresis integral $\mathrm{Rh}$, the critical volume $\mathrm{Vc}$ and its diameter Dc for superparamagnetic behavior, the magnetic viscosity coefficient $\mathrm{Sv}$, the activation volume Vact and its diameter Dact for bacterial magnetic particles (BMPs) and $\mathrm{Fe}_{3} \mathrm{O}_{4}$ particles (C1, C2, C3 and $\mathrm{C} 4$ ) prepared by the chemical coprecipitation method.

\begin{tabular}{lccccccc}
\hline Sample & $\begin{array}{c}\text { HA, ave } \\
(\mathrm{kA} / \mathrm{m})\end{array}$ & $\mathrm{Rh}$ & $\begin{array}{c}\mathrm{Vc} \\
\left(\times 10^{-24} \mathrm{~m}^{3}\right)\end{array}$ & $\begin{array}{c}\mathrm{Dc} \\
(\mathrm{nm})\end{array}$ & $\begin{array}{c}\mathrm{Sv} \\
(\mathrm{A} / \mathrm{m})\end{array}$ & $\begin{array}{c}\text { Vact } \\
\left(\times 10^{-24} \mathrm{~m}^{3}\right)\end{array}$ & $\begin{array}{c}\text { Dact } \\
(\mathrm{nm})\end{array}$ \\
\hline BMPs & 35.8 & 1.12 & 11 & 22 & 127 & 61 & 39 \\
C1 & 68.5 & 0.62 & 6 & 18 & 255 & 29 & 31 \\
C2, C3 & 109.8 & 0.67 & 4 & 15 & 88 & 85 & 44 \\
C4 & 127.4 & 0.95 & 3 & 14 & 151 & 49 & 37 \\
\hline
\end{tabular}

\section{CONCLUSIONS}

The calculated value of the saturation magnetization for BMPs was found to be $1.06 \times 10^{-4} \mathrm{~Wb} \mathrm{~m} / \mathrm{kg}(84.7$ emu/g) using Mossbauer spectroscopy and chemical analysis. The rotational hysteresis iniegrals for BMPs and $\mathrm{Fe}_{3} \mathrm{O}_{4}$ particles $(\mathrm{C} 1, \mathrm{C} 2$ and $\mathrm{C} 3$ ) were $1.12,0.62,0.67$ and 0.67 , respectively. They are considered to have different magnetization reversal mechanisms. The magnetic viscosity coefficient of BMPs was $50 \%$ smaller than that of $\mathrm{Fe}_{3} \mathrm{O}_{4}$ particles (C1) which has a smaller activation volume (Vact). It is concluded that BMPs is magnetically more stable than $\mathrm{C} 1$. The relations V $\geqq$ Vact and V $\gg \mathrm{Vc}(\mathrm{V}:$ particle volume, Vc: critical volume for superparamagnetic behavior) are of significant importance for the magnetic stability of fine particles.

\section{Acknowledgments}

The authors would like to thank Mr. H. Nishioji of Toray Research Center Inc., who cooperated with them in the measurement of Mössbauer spectroscopy. Thanks are also due to Mr. T. Ochiai, executive director and Dr. S. Saito, executive director both of TDK Corp., for their continued encouragement.

\section{References}

[1] Matsunaga T., Sakaguchi T. and Tadokoro F.: Appl. Microbiol. Bacteriol.,35 (1991) 65-6551.

[2] Matsunaga T., Trends Biotechnol. 9 (1991) 91-95.

[3] Greenwood N.N. and Gibb T.C., Mössbauer Spectroscopy(Chapman and Hall Ltd.,London, 1971) pp.12-15.

[4] Jacobs I.S. and Luborsky F.E., J. Appl. Phys., 28 (1957) 467-473.

[5] Shtrihman S. and Treves D., J. Phys. Radium, 20 (1959) 286-289.

[6] Bottoni G., Cancolfo D. and Cecchetti A., IEEE Trans. Magn., 29 (1993) 2643-2645.

[7] Bean C.P. and Livingstone J.D., J. Appl. Phys., 30 (1959) 120s-129s.

[8] Néel L., J. Phys. Rad., 12 (1951) 339-351.

[9] Street R. and Woolley J.C., Proc. Soc., A62 (1949) 562-572.

[10]Gaunt P., Philos. Mag., 34 (1976) 775-780.

[11]Nishio H., J. Magn. Soc. Jpn., 13 S1 (1989) 697-702.

[12]Murad E. and Johnson J.H., in "Mössbauer Spectroscopy Applied to Inorganic Chemistry", edited by Long G.J., Iron Oxides and Oxyhydroxides (Plenum Press, New York, 1987) pp.508-516.

[13]Barbier J.C., Ann. Phys. (Paris) 9 (1954) 84-141. 